\title{
MERAIH KECERDASAN FINANSIAL BERDIMENSI SPIRITUAL DENGAN WAKAF
}

\author{
Diyah Ayu Zahrotul Jannah \\ Ahmad Haris \\ Badan Wakaf Indonesia (BWI) Jakarta \\ e-mail:d.ayu1834@gmail.com
}

\begin{abstract}
In the human world created by bringing the elements of intelligence, be it intelligence quotient or spiritual intelligence. This article aims to reveal the financial intelligence of spiritual dimension with the teachings of waqf. Data collection methods used are with documentation of some literature. The results of the study indicate that the economic downturn has resulted in the inability of education to make a person worse in religious knowledge. Low levels of religious understanding can also lead to more vulnerability to misguided teachings and easily provoked by radical ideas. With waqf, the results obtained from waqf funds can be used for operational costs and educational infrastructure facilities so that people can achieve intelligence and spiritual intelligence so it is not easily provoked by radical ideology and misleading teachings.
\end{abstract}

Keywords: Waqf, Spiritual Intelligence, and Waqf Educational Institutions. 


\section{Pendahuluhan}

Radikalisme yang melatar belakangi gerakan terorisme merupakan salah satu masalah yang kini dihadapi oleh negaranegara di Asia Tenggara, terutama Indonesia. Radikalisme sering kali digerakkan oleh pemahaman keagamaan yang sempit, perasaan tertekan, terhegemoni, tidak aman secara psikososial, serta ketidakadilan lokal dan global (Ayub dan Ibnu Katsir, 2010: 256). Dalam hal ini salah satu faktor penyebab timbulnya radikalisme adalah faktor kebodohan yang merupakan keterpurukan ekonomi yang dialami oleh sebagian lapisan masyarakat yang mengakibatkan ketidakmampuan dalam mengenyam pendidikan. Hal ini akan berakibat keterpurukan intelegensi dan pengetahuan bagi warga yang kurang mampu. Mereka tidak akan cukup dibekali oleh ilmu pengetahuan yang sedang berkembang. Juga akan lebih rentan terhadap pengaruhpengaruh yang datang dari pihak lain. Termasuk juga akan mudah diprovokasi oleh paham-paham radikal. Selain itu tingkat pemahaman agama yang rendah juga dapat mengakibatkan lebih rentan terpengaruh ajaran-ajaran yang menyesatkan (Muhammad Aloakov, 2012: 11-12).

Pada dasaranyaa manusia diciptakan dengan membawa unsur-unsur kecerdasan. Awalnya kecerdasan yang dipahami banyak orang hanya merupakan kecerdasan intelejensi (intelegency quotient), sesuai dengan perkembangan pengetahuan manusia, maka ditemukan tipe kecerdasan lainnya melalui penelitianpenelitian empiris dan longitudinal oleh para akademisi dan praktis psikologi, antara lain yaitu kecerdasan spiritual (Spiritual Quotient) (Peter Garlans, 2012: 171).Spiritualitas Islam merujuk pada paradigma tauhid dalam mewujudkan keseimbangan yang harmonis antara aspek dunia dan akhirat. Ini merupakan aspek penting dalam membina kekuatan yang diiringi keimanan terhadap kekuasaan Allah SWT atas segala aspek kehidupan. Spiritualitas Islam yang lahir dari diri setiap manusia mampu dimanfaatkan menjadi sebuah kekuatan berupa kecerdasan 
spiritual Islam, unsur ini ada pada diri setiap manusia sebagai anugerah Allah SWT yang bermanfaat bagi aktivitas kehidupan. Hasilnya ditemukan tujuh unsur kecerdasan spiritual menurut perspektif Islam, yaitu iman, takwa, moralitas, jujur, bertanggung jawab, tabligh (menyampaikan), fathanah (cerdas), disiplin, visioner, dan empati (Hanifiyah, 2016: 188).

Pada era seperti sekarang ini, banyak orang tak kenal lelah mengejar materi atau bahkan hidup hanya demi mengumpulkan harta duniawi. Dalam pendangan mereka, menyisihkan sebagaian harta untuk disumbangkan tentu merupakan suatu hal yang kontraproduktif. Islam mengajarkan adanya hidup sesudah mati. Islam juga memerintahkan manusia berbuat kebajikan sebanyakbanyaknya sebagai bekal kehidupan sesuadah mati. Salah satu bekal itu bisa diperoleh dengan jalan berwakaf (al-Awqaf, 2015: 5).

Sehingga berdasarkan dengan permasalah tersebut maka artikel ini akan menjawab permasalahan bagaimana peran wakaf dalam menangkal radikalisme dan bagaimana meraih kecerdasan finansial berdimensi spiritual dengan ajaran wakaf.

\section{Pembahasan}

\section{Konsep Wakaf}

\section{Pengertian wakaf}

Wakaf adalah menahan harta baik secara abadi maupun sementara untuk dimanfaatkan langsung atau tidak langsung, dan diambil manfaat hasilnya secara berulang-ulang di jalan kebaikan, umum maupun khusus. Definisi wakaf ini mengandung delapan hal: pertama, menahan harta agar tidak dikonsumsi atau digunakan secara pribadi. Kedua definisi wakaf ini mencakup harta, baik yang tetap dan tidak bisa bergerak seperti tanah dan bangunan, dan maupun berupa benda bergerak, seperti buku dan senjata, atau berupa barang seperti peralatan dan kendaraan, atau berupa uang seperti deposito dan pinjaman, atau bisa juga 
berupa manfaat yang mempunyai nilai uang seperti manfaat pengangkutan khusus orang sakit dan lanjut usia. Atau berupa manfaat dari harta benda tetap yang diwakafkan oleh penyewa. Ketiga mengandung pengertian melestarikan harta dan menjaga keutuhannya, sehingga memungkinkan untuk dimanfaatkan secara langsung atau diambil manfaat hasilnya secara berulangulang. Keempatdefinisi ini mengandung pengertian berulangulangnya manfaat dan kelanjutannya baik yang berlangsung lama, sebentar atau selamanya. Kelima definisi wakaf ini mencakup wakaf langsung yang mengahasilkan manfaat langsung dari harta atau benda yang diwakafkan. Keenam mencakup jalan kebaikan umum untuk keagamaan, sosial, dan lain sebagainya. Ketujuh mencakup pengertian wakaf menurut fikih dan Perundang-undangan, bahwa wakaf tidak terjadi kecuali dengan keinginan satu orang yaitu wakif saja. Kedelapan mencakup pentingnya penjagaan dan kemungkinan bisa diambil manfaatnya secara langsung atau dimanfaatkan hasilnya (Abdurohman, 2013: 14- 16).

Dari delapan hal di atas dapat disimpulkan bahwa wakaf berfungsi sebagai upaya untuk membangun kesejahteraan umat. Menurut Muhammad Daud Ali seperti yang dikutip Uswatun Hasanah kesejahteraan secara harfiah bermakna kemanan dan kesejahteraan hidup termasuk kemakmuran, yaitu konsep yang menunjukkan keadaan, dimana setiap orang baik sebagai individu maupun sebagai anggota masyarakat dapat memenuhi kebutuhannya dengan mudah. Dengan demikian yang dimaksud dengan kesejahteraan adalah keadaan orang hidup aman dan tentram serta dapat memenuhi kebutuhan hidupnya (Farid dan Mursid, 2007: 76).

Prinsip ajaran Islam ada pada sistem Zakat, Infak, Shadaqah, dan Wakaf yaitu anjuran untuk mengeluarkan sebagian rezeki yang diberikan Allah untuk menyantuni orangorang fakir, miskin dan orang-orang lemah dalam masyarakat. dengan demikian ajaran Islam terhadap pemerataan pendapatan sebenarnya bertujuan agar kehidupan setiap orang Islam terjamin 
dalam masalah ekonominya, konsentrasi kekayaan tidak hanya pada orang-orang kaya saja. Dan kalau keinginan Islam yang telah ditegaskan oleh Al-Qur'an ini tercapai, kesenjangan sosial sebagai jurang pemisah anatara si kaya dan miskin tidak akan terjadi (Farid dan Mursid, 2007: 77-78).

\section{Wakaf produktif}

Menurut Munzir Qahaf, wakaf produktif adalah memindahkan harta dari upaya konsumtif menuju produktif dan investasi dalam bentuk modal produksi yang dapat memproduksikan dan menghasilkan sesuatu yang dapat dimanfaatkan pada masa-masa mendatang, baik oleh pribadi, kelompok maupun oleh umum. Dengan demikian, wakaf produktif merupakan kegiatan menabung dan berinvestasi secara bersamaan (Abdurrohman, 2015: 14).

Sedangkan menurut Jaih Mubarok, wakaf produktif adalah transformasi dari pengelolaan wakaf yang profesional untuk meningkatkan atau menambah manfaat wakaf. Wakaf produktif juga dapat diartikan sebagai proses pengelolaan benda wakaf untuk menghasilkan barang atau jasa yang maksimum dengan modal yang minimum. Untuk memberdayakan aset wakaf menjadi produktif, ada lima strategi untuk memberdayakan wakaf agar menjadi wakaf produktif, yaitu: pertama, mengenali potensi perputaran harta wakaf dengan melihat sejarah atau model wakaf yang sudah berjalan dan melakukan pembaruan pada sistem wakaf. Kedua, memfasilitasi pengembangan model wakaf modern dengan menerapkan teknik manajemen modern pada wakaf, sepanjang tujuannya tidak bertentangan dengan prinsip-prinsip syari'ah. Ketiga, mempromosikan filantropi Islam melalui wakaf, sehingga wakaf dapat menjadi tulang punggung bagi masyarakat dan berpotensi memainkan peran penting dalam pelayanan masyarakat. Disamping itu, wakaf produktif dapat menjadi alternatif pada masa krisis ketika pemerintah sudah tidak sanggup lagi memenuhi kebutuhan masyarakat. Keempat, 
memodernisasi administrasi wakaf, sehingga struktur manajemen wakaf dapat menjadi lebih efisien, transparan dan responsif serta menjalin kerjasama teknis dan bertukar pengalaman dengan lembaga pendidikan, organisasi internasional dan negara lain untuk mengembangkan investasi wakaf. Kelima, memproduktifkan wakaf yang sebelumnya tidak produktif dengan membangkitkan komitmen dari wakif, nadzir, investor dan masyarakat sekitarnya yang mengetahui benefit dari wakaf tersebut (Abdurrohman, 2015: 15).

Wakaf merupakan pilar penyelenggara bagi tegaknya institusi-institusi sosial-keagamaan masyarakat muslim selama berabad-abad. Hal itu dilakukan melalui penyedia dana dan sarana pendukung bagi kegiatan-kegiatan ritual keagamaan, pendidikan, pengembangan ilmu pengetahuan, seni dan budaya (Abdurrohman, 2015: 16).

\section{Peran wakaf untuk pendidikan}

Semakin cepatnya perkembangan ilmu pengetahuan dan teknologi, khususnya di bidang informasi mempunyai dampak yang sangat dahsyat dalam kehidupan. Terbukanya pintu pasar bebas yang memberikan peluang kesempatan persaingan yang sangat ketat, derasnya arus demokratisasi, HAM, isu-isu lingkungan dan lain sebagainya merupakan tantangan yang harus segera dijawab oleh umat Islam agar tetap survive, bahkan bisa memenangkan kompetisi dalam percaturan kehidupan internasional. Untuk menjawab beberapa tantangan di atas, diantaranya dengan meningkatkan dan memperbaiki kualitas pendidikan umat Islam. Karena pendidikan adalah media yang paling utama dalam menciptakan SDM yang berkualitas (Abdurrohman, 2015: 165).

Wakaf produktif adalah harta benda atau pokok tetap yang diwakafkan untuk dipergunakan dalam kegiatan produksi dan hasilnya disalurkan sesuai dengan tujuan wakaf. Salah satu upaya strategis untuk meningkatkan kualitas pendidikan 
umat Islam adalah melalui gerakan wakaf produktif untuk pendidikan. Disebut produktif, karena dana wakaf digunakan dan diinvestasikan untuk membiayai usaha-usaha produktif sedangkan hasilnya diperuntukkan bagi kepentingan sosial umat, seperti beasiswa pendidikan. Wakaf memiliki peran sangat penting dalam meningkatkan kesejahteraan guru dan dosen, memperbaiki sarana prasarana, meningkatkan kualitas pendidikan, perbaikan kurikulum dan perbaikan manajemen pendidikan, serta meningkatkan partisipasi masyarakat dalam penyelenggaraan pendidikan (Abdurrohman, 2015: 166).

Wakaf pendidikan dipilih karena instrumen ini potensial untuk dikembangkan menjadi sumberdaya (resources) umat yang sangat strategis. Pengelolaan pendidikan publik dengan menggunakan lembaga wakaf juga dimaksudkan untuk mencegah terjadinya klaim kepemilikan dari pihak-pihak tertentu, kerana lembaga wakaf pada hakikatnya merupakan public trust(Abdurrohman, 2015: 167).

\section{Kecerdasan Finansial Berdimensi Spiritual Melalui Wakaf Ruang lingkup kecerdasan sipritual}

Kecerdasan spiritual (SQ) adalah kecerdasan yang bertumpu pada bagian dalam diri kita yang berhubungan dengan kearifan di luar ego atau jiwa sadar. Hal utama dalam kecerdasan spiritual adalah pengenalan akan kesejatian diri manusia. Kecerdasan spiritual bukan sebuah ajaran teologis, kecerdasan ini secara tidak langsung berkaitan dengan agama. Kecerdasan spiritual ini mengarahkan manusia pada pencarian hakikat kemanusiannya. Hakikat manusia dapat ditemukan dalam perjumpaan atau saat berkomunikasi antara manusia dengan Allah SWT. Oleh karena itu, ada yang berpandangan bahwa kecerdasan spiritual (SQ) adalah kecerdasan manusia yang digunakan untuk berhubungan dengan Tuhan. Asumsinya adalah jika seseorang berhubungan dengan Tuhannya baik, maka 
bisa dipastikan hubungan dengan sesama manusia pun akan baik pula (Novan Ady, 2012: 63).

Dengan SQ manusia bisa mengobati penyakit dirinya sendiri, akibat krisis multidimensi yang melanda manusia modern saat ini seperti krisis eksistensi, krisis spiritual dan atau krisis makna. SQ adalah jenis kecerdasan untuk menghadapi dan memecahkan persoalan makna dan nilai, yaitu kecerdasan untuk menempatkan perilaku dan hidup kita dalam konteks makna yang lebih luas dan kaya (Abdul Wahid, 2006: 29). Kecerdasan spriritual merupakan salah satu kecerdasan salah satu bentuk kecerdasan yang akan menjadi pondasi utama untuk lebih mengefektifkan kecerdasan intelektual (IQ) dan kecerdasan emosional (EQ). SQ merupakan bentuk kecerdasan yang bisa menempatkan kehidupan individual kita dalam konteks yang lebih luas. SQ ini sangat dibutuhkan dalam budaya masyarakat yang oleh Zohar dan Marshall disebut juga sebagai spiritual dumb culture (budaya yang bodoh secara spiritual) yang ditandai dengan materialisme, kelayakan, egoisme diri yang sempit dan kehilangan makna dan kekurangan komitmen. Dengan sangat meyakinkan sekali, Tanis Helliwell mengatakan bahwa dengan memiliki SQ, tingkat kesuksesan hidup seseorang pada dekade yang akan datang akan meningkat (Abdul Wahid, 2006: 41).

Dalam terminologi Islam, dapat dikatakan bahwa SQ adalah kecerdasan yang bertumpu pada qalb. Qalb inilah yang sebenarnya merupakan pusat kendali semua gerak anggota tubuh manusia. Ia adalah raja bagi semua anggota tubuh yang lain. Semua aktivitas manusia berada di bawah kendalinya. Jika qalb ini sudah baik, maka gerak dan aktifitas anggota tubuh yang lain akan baik pula,demikian juga sebaliknya (Abdul Wahid, 2006: 63).

\section{Meraih kecerdasan finansial dengan wakaf}

Wakaf merupakan bentuk kecerdasan finansial tingkat tinggi yang berdimensi spiritual dan menjanjikan keuntungan 
tak terbatas waktu dan jumlahnya. Dengan berwakaf sekali saja dalam seumur hidup, sama saja dengan berbisnis investasi yang memberikan penghasilan pasif (passive income) tak terhitung nilainya. Tanpa berpeluh ria, investor bisa mendapatkan keuntungan yang datang dengan sendirinya. Dengan wakaf, jika dikelola secara produktif, profesional, dan amanah, nilai nominal harta wakaf akan bertambah, penerima manfaatnya semakin banyak dan luas dan seorang wakif bisa mendapatkan pahala terus-menerus dan semaki besar meski ia sudah meninggal dan tidak tidak ikut serta mengelola harta yang ia wakafkan (alAwqaf, 2015: 5-6).

Selain merupakan suatu kecerdasan finansial berdimensi spriritual, wakaf mempunyai hikmah dan manfaat lainnya, yaitu: pertama, wakaf menjamin harta terus mengalirkan pahala karena harta wakaf tidak boleh berpindah kepemilikan. Kalaupun berpindah kepemilikan karena ditukar (ruilslaag), ada penggantinya dan biasanya lebih baik. Kedua, jika dikelola secara produktif, profesional, dan amanah; nilai nominal harta wakaf akan bertambah, penerima manfaatnya semakin banyak dan luas, dan pahala bagi wakif diyakini akan semakin besar. Ketiga, wakif akan mendapatkan berkah doa dari orang-orang yang mendapatkan manfaat dari harta wakaf. Keempat, wakaf menjadikan wakif tetap hidup dan meninggalkan nama baik meski sudah meninggal. Keenam, wakaf melindungi harta dari penjarahan politik akibat pergantian kuasa (al-Awqaf, 2015: 5-6).

\section{Peran wakaf dalam menangkal radikalisme}

Radikalisme merupakan paham atau aliran yang menginginkan perubahan atau pembaharuan soasial dan politik dengan cara kekerasan atau drastis. Radikalisme bisa dibedakan ke dalam dua level, yaitu level pemikiran dan level aksi atau tindakan. Pada level pemikiran, radikalisme masih berupa wacana, konsep dan gagasan yang masih diperbincangkan, yang intinya mendukung penggunaan cara-cara kekerasan 
untuk mencapai tujuan. Salah satu faktor yang menyebabkan terjadinya radikalisme adalah faktor kebodohan yang merupakan keterpurukan ekonomi yang dialami oleh sebagian lapisan masyarakat yang mengakibatkan ketidakmampuan dalam mengenyam pendidikan. Hal ini akan berakibat keterpurukan intelegensi dan pengetahuan bagi warga yang kurang mampu.

Dalam hal ini, untuk menyelesaikan permasalah tersebut, maka peran wakaf sangat dibutuhkan, salah satunya wakaf untuk pendidikan, dana wakaf atau dana hasil wakaf yang digunakan untuk pendidikan, misalnya untuk membangun lembaga pendidikan atau digunakan untuk biaya opersional atau fasilitas pendidikan akan sangat membantu orang-orang yang tidak mampu dalam mengeyam pendidikan dan kurang ilmu pengetahuan, karena seseorang yang ilmu pengetahuan dan pendidikannya kurang akan rentan terpengaruh dan mudah terprovokasi oleh paham radikal serta tingkat pemahaman agama yang rendah juga dapat mengakibatkan lebih rentan terpengaruh ajaran-ajaran yang menyesatkan.

Dana wakaf yang digunakan untuk pendidikan sangat membantu orang-orang dalam mengembangkan potensi dirinya untuk memiliki kekuatan spiritual keagamaan, pengendalian diri, kepribadian, kecerdasan dan akhlak mulia. Sehingga dalam hal ini, mereka tidak akan mudah terpengaruh dengan paham-paham radikal serta ajaran-ajaran yang menyesatkan.

Pengelolaan wakaf yang bersifat produktif ini, sejalan dengan apa yang pernah diungkapkan Ibnu Khaldun seperti yang dikutip M. Umer Chapra; bahwa Ibnu Khaldun sangat menekankan peranan investasi untuk harta kekayaan yang dimiliki. Dia berujar bahwa kekayaan akan tumbuh dan berkembang dan bahka bertambah manakala kekayaan tersebut dihabiskan untuk kesejahteraan masyarakat, memenuhi hak-hak masyarakat, serta mengurangi penderitaan masyarakat. Pada akhirnya masyarakat akan menjadi semakin baik, memperkuat 
negara, menjadi negara makmur, dan mencapai kewibawaan negara atau daulah (Farid dan Mursyid, 2007:79).

\section{Meraih kecerdasan finansial berdimensi spiritual melalui ajaran wakaf}

Kecerdasan spiritual adalah kecerdasan jiwa atau kecerdasan kearifan, dan kecerdasan ini merupakan kapasitas bawaan dari otak manusia, spiritualitas berdasarkan strukturstruktur dari dalam otak yang memberi kita kemampuan dasar membentuk, nilai, makna dan tujuan. Oleh karena itu orang perlu menemukan, mengelola dan mengoptimalkan atau mendayagunakan nilai-nilai kearifan yang dimilikinya untuk mencapai suatu tujuan yang mulia atau tujuan yang membuat dirinya benar-benar bermakna. Lebih lanjut, dengan kecerdasan spiritual memberikan kemampuan untuk membedakan, memungkinkan seseorang untuk memberikan batasan serta mampu memberikan kita rasa moral.

Untuk mencapai kecerdasan tersebut maka diperlukan pendidikan serta ilmu pengetahuan agama yang kuat. Namun, pada dasarnya orang-orang tidak dapat mendapatkan pendidikan serta ilmu pengetahuan agama karena kurangnya kualitas pendidikan. Dalam hal ini wakaf sangat berperan penting untuk memecahkan masalah tersebut. Karena mayoritas pemanfaatan hasil wakaf digunakan untuk pembangunan pendidikan. Untuk meningkatkan kualitas pendidikan dan ilmu pengetahuan, lembaga wakaf yang dibuat untuk lembaga pendidikan (madrasah, pesantren) dimana memiliki struktur kurikulum pendidikan. Kurikulum merupakan suatu instrumen untuk mencapai tujuan.Oleh karena itu, hasilnya harus dapat memenuhi tujuan yang dikehendaki. Jadi, fungsi kurikulum di sini adalah sebagai instrumen atau jembatan untuk mencapai tujuan yang telah ditetapkan. Dalam hal ini struktur kurikulum pendidikan harus menggunakan pola organisasi kurikulum yang bersifat efektif, yaitu memadukan kurikulum yang bersifat 
subject curriculum, correlated curriculum, integrated curriculum, core atau intra-curiculum, dan extra curiculum. Subject curiculum terkait dengan pentingnya memahami materi ilmu agama; dengan corelated terkait dengan sifat materi agama Islam yang berkaitan antara satu dengan yang lainnya; dengan integrated terkait dengan sifat ajaran Islam yang tidak mengenal pemisahan antara ilmu ilmu agama dan ilmu agama lain, dan antara ilmu agama dengan ilmu umum; dan dimaksud dengan core curiculum adalah kurikulum yang bersifat inti atau dasar, terkait dengan akidah, ibadah, dan akhlak mulia; dan extra curiculum terkait dengan berbagai kegiatan yang bernuansa agamis (Abbudin, 2016: 114).

Kurikulum merupakan inti dari bidang pendidikan dan memiliki pengaruh terhadap seluruh kegiatan pendidikan. Mengingat pentingnya kurikulum dalam pendidikandan kehidupan manusia, maka penyusunan kurikulum tidak dapat dilakukan secara sembarangan. Penyusunan kurikulum membutuhkan landasan-landasan yang kuat, yang didasarkan pada hasil-hasil pemikiran dan penelitian yang mendalam. Penyusunan kurikulum yang tidak didasarkan pada landasan yang kuat dapat berakibat fatal terhadap kegagalan pendidikan itu sendiri. Dengan sendirinya, akan berakibat pula terhadap kegagalan proses pengembangan manusia. Landasan-landasan dalam pengembangan kurikulum tersebut meliputi:

Pertama, Landasan Filosofi, secara ontologism, manusia memiliki potensi jismiyah, nafsiyah yang mengandung dimensi alnafsu, al-agl dan al-qalb, dan potensi ruhiyah yang memancar dari dimensi al-ruh dan al-fitrah, sehingga ia siap untuk mengadakan hubungan vertikal dan horizontal. Perkembangan hubungan vertikal maupun horizontal ini tak lepas dari aliran filsafat yang mempengauhi manusia itu snediri, termasuk dalam hal penerapan kurikulum. Sama halnya seperti dalam Filsafat Pendidikan, kita dikenalkan pada berbagai aliran filsafat, seperti: perenialisme, essensialisme, eksistesialisme yang merupakan aliran filsafat yang mendasari terhadap pengembangan Model Kurikulum Subjek 
-Akademisi, sedangkan filsafat progresivisme memberikan dasar bagi pengembangan Model Kurikulum Pendidikan Pribadi, sementara filsafat rekonstruktivisme banyak diterapkan dalam pengembangan Model Kurikulum Interaksional. Dalam pengembangan kurikulum pun senantiasa berpijak pada aliran-aliran filsafat tertentu, sehingga akan mewarnai terhadap konsep dan implementasi struktur kurikulum yang dikembangkan.

Kedua, Landasan Psikologis, merupakan bidang psikologi yang mendasari pengembangan kurikulum yang terdiri dari psikologi perkembangan dan psikologi belajar. Psikologi perkembangan merupakan ilmu yang mempelajari tentang perilaku individu berkenaan dengan perkembangannya. Sedangkan psikologi belajar merupakan ilmu yang mempelajari tentang perilaku individu dalam konteks belajar.

Ketiga, Landasan Sosial-Budaya, dalam landasan ini, kurikulum dapat dipandang sebagai suatu rancangan pendidikan. Sebagai suatu rancangan, kurikulum menentukan pelaksanaan dan hasil pendidikan. Kita maklumi bahwa pendidikan merupakan usaha mempersiapkan peserta didik untuk terjun ke lingkungan masyarakat. Karena pada dasarnya pendidikan bukan hanya untuk pendidikan semata, namun memberikan bekal pengetahuan, keterampilan serta nilai-nilai untuk hidup,bekerja dan mencapai perkembangan lebih lanjut di masyarakat.

Keempat, Landasan Ilmu Pengetahuan dan Teknologi, ilmu pengetahuan dan teknologi yang dimiliki manusia masih relatif sederhana. Perkembangan dalam bidang Ilmu Pengetahuan dan Teknologi terutama dalam bidangb transportasi dan komunikasi telah mampu merubah tatanan kehidupan manusia. Oleh karena itu, kurikulum seyogyanya dapat mengakomodir dan mengantisipasi laju perkembangan ilmu pengetahuan dan teknologi, sehingga peserta didik dapat mengimbangi dan sekaligus mengambangkan ilmu pengetahuan dan teknologi untuk kemaslahatan dan kelangsungan hidup manusia (Sulistyorini dan Fathurrohman, 2014: 78-85). 
Dengan struktur kurikulum pendidikan yang memiliki landasan-landasan yang kuat melalui pendidikan diharapkan dapat lebih mengerti dan mampu membangun kehidupan masyarakat. dalam hal ini, proses pendidikan harus disesuaikan dengan kebutuhan, kondisi, karakteristik, kekayaan dan perkembangan yang ada di masyarakat.

Peran wakaf yang digunakan untuk pendidikan sangat dibutuhkan bagi orang-orang yang kurang pemahaman tentang ilmu pengetahuan, terutama tentang pengetahuan agama. Dengan kualitas pendidikan yang baik maka diharapkan akan memberikan dampak yang baik pula terhadap pengeyam pendidikan sehingga akan terbebas dari paham-paham radikal serta ajaran-ajaran yang menyesatkan. Karena wakaf dan pendidikan berputar dalam satu lingkaran, masing-masing dipengaruhi oleh yang sebelumnya dan mempengaruhi yang sesudahnya. Ketika banyak orang yang berwakaf untuk pendidikan, maka makmurlah lembagalembaga pendidikan dan lembaga riset yang selanjutnya menghasilkan banyak orang-orang pandai yang nantinya juga akan mengeluarkan wakaf. Dalam hal ini, wakaf bertujuan untuk mensejahterakan umat terutama untuk mensejahterakan pendidikan agar para pengenyam pendidikan dapat merasakan kualitas pendidikan yang benar-benar memiliki landasan struktur kurikulum yang baik dan kuat, dengan kualitas yang baik, maka bukan tidak mungkin bahwa para pengenyam pendidikan akan mendapatkan pendidikan serta ilmu pengetahuan terutama pengetahuan tentang agama yang berkualitas, sehingga akan terhindar oleh paham-paham radika serta ajaran-ajaran yang menyesatkan.

\section{Simpulan}

Faktor kebodohan yang merupakan keterpurukan ekonomi yang dialami oleh sebagian lapisan masyarakat yang mengakibatkan ketidakmampuan dalam mengenyam pendidikan. Hal ini akan berakibat keterpurukan intelegensi dan pengetahuan 
bagi warga yang kurang mampu. Tingkat pemahaman agama yang rendah juga dapat mengakibatkan lebih rentan terpengaruh ajaran-ajaran yang menyesatkan dan mudah terprovokasi pahampaham radikal. Namun, ada salah satu cara untuk menangkal permasalahan tersebut, yaitu dengan ajaran wakaf. Dengan wakaf, nantinya dana wakaf atau dana hasil wakaf dapat digunakan untuk biaya operasional dan sarana prasarana untuk pendidikan agar orang-orang dapat meraih kecerdasan yang berdimensi spiritual agar tidak mudah terprovokasi oleh paham-paham radikal serta ajaran-ajaran yang menyesatkan.

Untuk meraih kecerdasan yang berdimensi spiritual, maka pendidikan sangat dibutuhkan agar terhindar dari pahampaham radikal serta ajaran-ajaran yang menyesatkan. Dalam hal ini wakaf sangat berperan penting untuk memecahkan masalah tersebut. Karena mayoritas pemanfaatan hasil wakaf digunakan untuk pembangunan pendidikan. Untuk meningkatkan kualitas pendidikan dan ilmu pengetahuan, lembaga wakaf yang dibuat untuk lembaga pendidikan (madrasah, pesantren) dimana memiliki struktur kurikulum pendidikan. Dalam hal ini struktur kurikulum pendidikan harus menggunakan pola organisasi kurikulum yang bersifat efektif, yaitu memadukan kurikulum yang bersifat subject curriculum, correlated curriculum, integrated curriculum, core atau intra-curiculum, dan extra curiculum.

Penyusunan kurikulum yang tidak didasarkan pada landasan yang kuat dapat berakibat fatal terhadap kegagalan pendidikan itu sendiri. Dengan sendirinya, akan berakibat pula terhadap kegagalan proses pengembangan manusia. Landasanlandasan dalam pengembangan kurikulum tersebut meliputi: landasan filosofi, landasan psikologis, landasan sosial-budaya, serta landasan ilmu pengetahuan dan teknologi.

Dengan kualitas pendidikan yang baik maka diharapkan akan memberikan dampak yang baik pula terhadap pengeyam pendidikan sehingga akan terbebas dari paham-paham radikal serta ajaran-ajaran yang menyesatkan. 


\section{Daftar Pustaka}

Abbudin Nata, Inovasi Pendidikan Islam, Salemba Diniyah, Jakarta, 2016.

Abdul Wahid Hasan, SQ Nabi Aplikasi Strategi dan Model Kecerdasan Spiritual (SQ) Rasulullah Di Masa Kini, Idea Press, Yogyakarta, 2006.

Abdurrohman Kasdi, Fikih Wakaf: Dari Wakaf Klasik Hingga Wakaf Produktif, Idea Press, Yogyakarta, 2013

Abdurrohman Kasdi, Wakaf Produktif Untuk Pendidikan Model Pengelolaan Wakaf Produktif Al-Azhar Asy-Syarif Cairo Mesir, Idea Press, Yogyakarta, 2015.

Al-Awqaf Buletin Wakaf Badan Wakaf Indonesia, Meraih Kecerdasan Finansial Berdimensi Spiritual Melalui Berwakaf, No. 1, 2015.

Ayub Mursalin dan Ibnu Katsir, Pola Pendidikan Keagamaan Pesantren dan Radikalisme: Studi Kasus Pesantren pesantren diProvinsi Jambi,Kontekstualita, Vol. 25, No. 2, 2010.

Farid Wadjdy dan Mursyid, Wakaf Dan Kesejahteraan Umat (Filantropi Islam Yang Hampir Terlupakan), Pustaka Pelajar, Yogyakarta, 2007.

Hanifiyah Yuliatul Hijriah, Spiritualitas Islam Dalam Kewirausahaan, Jurnal Peradaban Islam, Vol. 12, No. 1, Mei 2016.

Muhammad Aloakov, Berkembangnya Radikalisme Di Perguruan Tinggi, Jurusan Sistem Informasi, Sekolah Tinggi Informatika dan Komputer Amikom, Yogyakarta, 2012.

Novan Ady Wiyani, Pendidikan Karakter Berbasis Iman Dan Taqwa, Teras, Yogyakarta, 2012.

Peter Garlans Sina, Pengaruh Kecerdasan Spiritual Terhadap Pengelolaan Keuangan Pribadi,Jurnal Manajemen, Vol. 11, No. 2, Mei 2012.

Sulistyorini dan Muhammad Fathurrohman, Esensi Manajemen Pendidikan Islam (Pengelolaan Lembaga Untuk Meningkatkan Kualitas Pendidikan Islam), Teras, Yogyakarta, 2014. 